\title{
PENGARUH INFLASI DAN NILAI TUKAR TERHADAP INDEKS SAHAM SYARIAH INDONESIA
}

\author{
Octavia Setyani \\ GENBI UIN Sultan Maulana Hasanuddin Banten \\ E-mail: octaviavivi10@gmail.com
}

\begin{abstract}
The Influence of Inflation and Exchange Rate against the Indonesian Sharia Stock Index. Indonesian Sharia Stock Index (ISSI) is a stock index that reflects the total sharia stock recorded on the Indonesia Stock Exchange and registered in the List of Sharia Securities. Judging from the movement of ISSI that experienced a significant development of course it is influenced by some macroeconomic and monetary variables, such as inflation, money supply, exchange rates, and others. The purpose of this research 1) To find out the partial effect between inflation and exchange rate on Indonesia Sharia Stock Index, 2) To know the effect simultaneously between inflation and exchange rate against Indonesia Sharia Sharia Index, 3) To know the magnitude of influence between inflation and exchange rate against the Indonesia Sharia Shares Index. This research uses descriptive analysis method, classical assumption test, multiple regression analysis, $F$ test, $t$ test, correlation coefficient, and coefficient of determination with the help of SPSS program. Based on the test results indicate that the variable of inflation is partially no significant effect on Indonesia Sharia Stock Index. It can be seen from the value of $t$ arithmetic on the variable of inflation is smaller than $t_{\text {table, }}$ that is ($1.097<2.002)$, and significance value greater than 0.05, that is $(0.277>0.05)$. And the exchange rate variable partially has no significant effect on Indonesia Sharia Stock Index. It can be seen from the value of $t$ arithmetic on the variable of exchange rate is smaller than $t_{\text {table, }}$ that is $(-1,493<2,002)$, and significance value greater than 0,05 , that is $(0,141>0,05)$. While the inflation and exchange rate variables simultaneously have no significant effect on Indonesia Sharia Stock Index. It can be seen from the value of $F$ arithmetic smaller than $F$ table, that is $(1,934<3,16)$, and significance value greater than 0,05 , that is $(0,154>0,05)$. The result of calculation of coefficient of determination $\left(R^{2}\right)$ is equal to 0,064 . This means that the inflation and exchange rate variables can explain the effect on the Indonesia Sharia Stock Index of 6.4\% while the remaining $93.6 \%$ is explained by other variables outside the research.
\end{abstract}

Keywords: Inflation, Exchange Rate, Sharia Stock Index Indonesia.

Abstrak. Pengaruh Inflasi dan Nilai Tukar Terhadap Indeks Saham Syariah Indonesia. Indeks Saham Syariah Indonesia (ISSI) merupakan indeks saham yang mencerminkan keseluruhan saham syariah yang tercatat di Bursa Efek Indonesia dan terdaftar dalam Daftar Efek Syariah. Dilihat dari pergerakan ISSI yang mengalami perkembangan signifikan tentu hal tersebut dipengaruhi oleh beberapa variabel makroekonomi dan moneter, seperti inflasi, jumlah uang beredar, nilai tukar, dan lain- 
Islamiconomic: Jurnal Ekonomi Islam

Vol.8 No.2 Juli - Desember 2017

$\overline{\text { lain. Penelitian ini bertujuan 1) Untuk mengetahui pengaruh secara parsial antara }}$ inflasi dan nilai tukar terhadap Indeks Saham Syariah Indonesia, 2) Untuk mengetahui pengaruh secara simultan antara inflasi dan nilai tukar terhadap Indeks Saham Syariah Indonesia, 3) Untuk mengetahui besarnya pengaruh antara inflasi dan nilai tukar terhadap Indeks Saham Syariah Indonesia. Penelitian ini menggunakan metode analisis deskriptif, uji asumsi klasik, analisis regresi berganda, uji $F$, uji $t$, koefisien korelasi, dan koefisien determinasi dengan bantuan program SPSS. Berdasarkan hasil pengujian menunjukkan bahwa variabel inflasi secara parsial tidak berpengaruh signifikan terhadap Indeks Saham Syariah Indonesia. Hal ini dapat dilihat dari nilai $t$ hitung pada variabel inflasi lebih kecil dari $t$ tabel, yaitu $(-1,097<2,002)$, serta nilai signifikansi yang lebih besar dari 0,05, yaitu $(0,277>0,05)$. Dan variabel nilai tukar secara parsial tidak berpengaruh signifikan terhadap Indeks Saham Syariah Indonesia. Hal ini dapat dilihat dari nilai $t$ hitung pada variabel nilai tukar lebih kecil dari $t$ tabel, yaitu $(-1,493<2,002)$, serta nilai signifikansi yang lebih besar dari 0,05, yaitu $(0,141>0,05)$. Sedangkan variabel inflasi dan nilai tukar secara simultan tidak berpengaruh signifikan terhadap Indeks Saham Syariah Indonesia. Hal ini dapat dilihat dari nilai $F_{\text {hitung }}$ lebih kecil dari $F_{\text {tabel, }}$ yaitu $(1,934<3,16)$, serta nilai signifikansi yang lebih besar dari 0,05, yaitu $(0,154>0,05)$. Adapun hasil perhitungan koefisien determinasi $\left(R^{2}\right)$ adalah sebesar 0,064. Hal ini berarti variabel inflasi dan nilai tukar dapat menjelaskan pengaruhnya terhadap Indeks Saham Syariah Indonesia sebesar 6,4\% sedangkan sisanya 93,6\% dijelaskan oleh variabel lain diluar penelitian.

Kata Kunci: Inflasi, Nilai Tukar, Indeks Saham Syariah Indonesia.

\section{Pendahuluan}

Dewasa ini istilah investasi dan penanaman modal merupakan dua istilah yang cukup dikenal dalam kegiatan bisnis dan kegiatan perundang-undangan. Istilah investasi lebih popular dalam dunia usaha, sedangkan istilah penanaman modal lebih banyak digunakan dalam bahasa perundang-undangan. Di kalangan masyarakat luas, kata investasi memiliki pengertian yang lebih luas karena dapat mencakup baik investasi langsung (direct investment) maupun investasi tidak langsung (portofolio investment), sedangkan dalam penanaman modal lebih mempunyai konotasi kepada investasi langsung. Namun dalam istilah sehari-hari sering digunakan istilah investasi terutama dalam kegiatan pasar uang dan pasar modal saat ini. ${ }^{1}$

Menurut Kamaruddin Ahmad, ada beberapa alasan mengapa seseorang melakukan investasi, diantaranya adalah untuk mendapat kehidupan yang lebih layak di masa yang akan datang, untuk mengurangi tekanan inflasi, dan dorongan untuk menghemat pajak. ${ }^{2}$ 
Octavia Setyani: Pengaruh Inflasi dan...

Di samping hal tersebut orang melakukan investasi karena dipicu oleh kebutuhan akan masa depan. Tetapi sangat disayangkan, banyak orang belum memikirkan kebutuhan akan masa depannya. Padahal semakin ke depan, biaya hidup seseorang pasti akan semakin bertambah. Bila orang menyadari bahwa kebutuhan masa depan akan lebih besar, mereka tentu akan menyempatkan diri berhemat dalam mengelola keuangannya, mereka pasti akan melakukan investasi guna memenuhi kebutuhan yang diperlukan itu.

Selain kebutuhan akan masa depan, orang melakukan investasi karena dipicu oleh banyaknya ketidakpastian atau hal-hal lain yang tidak terduga dalam hidup ini, misalnya keterbatasan dana, kondisi kesehatan, datangnya musibah secara tiba-tiba, dan kondisi pasar investasi. Oleh karena masalah ini tidak dapat diprediksi dengan tepat, maka diperlukan perencanaan yang baik dalam menghadapi hidup ini. Dengan adanya alternatif instrumen investasi, memungkinkan seseorang bisa memenuhi kebutuhan masa depannya dengan menentukan prioritas kebutuhan, menetapkan perencanaan yang baik, dan implementasi secara disiplin. ${ }^{3}$

Pada umumnya investasi dibedakan menjadi dua, yaitu investasi pada financial asset dan investasi pada real asset . Investasi pada financial asset dilakukan di pasar uang, misalnya berupa sertifikat deposito, commercial paper, Surat Berharga Pasar Uang (SBPU), dan lainnya. Investasi juga dapat dilakukan di pasar modal, misalnya berupa saham, obligasi, warrant, opsi, dan yang lainnya. Sedangkan investasi pada real asset dapat dilakukan dengan pembelian aset produktif, pendirian pabrik, pembukaan pertambangan, perkebunan, dan yang lainnya. ${ }^{4}$ Salah satu kegiatan investasi yang dipilih oleh investor adalah berinvestasi pada pasar modal syariah.

Indonesia sebagai salah satu negara muslim terbesar di dunia merupakan pasar yang sangat besar untuk pengembangan industri keuangan syariah. Investasi syariah di pasar modal yang merupakan bagian dari industri keuangan syariah mempunyai peranan yang cukup penting untuk meningkatkan pangsa pasar industri keuangan syariah di Indonesia.

Perkembangan pasar modal syariah di Indonesia mengalami pergerakan yang cukup pesat walaupun masih tergolong baru dibandingkan dengan pasar modal konvensional yang sudah berdiri sejak zaman kolonial Belanda pada tahun 1912 di 
Islamiconomic: Jurnal Ekonomi Islam Vol.8 No.2 Juli - Desember 2017

Batavia. Dimulai dengan diterbitkannya Reksa Dana Syariah oleh PT. Danareksa Investment Management pada tanggal 3 Juli 1997. Selanjutnya, Bursa Efek Indonesia bekerja sama dengan PT. Danareksa Investment Management meluncurkan Jakarta Islamic Index (JII) pada tanggal 3 Juli 2000 yang bertujuan untuk memandu investor yang ingin menginvestasikan dananya secara syariah. Pada tanggal 12 Mei 2011 diluncurkan kembali Indeks Saham Syariah selain JII, yaitu Indeks Saham Syariah Indonesia (ISSI). Peluncuran Indeks Saham Syariah Indonesia (ISSI) atau Indonesian Sharia Stock Index (ISSI) yang dimaksudkan untuk menjadi acuan bagi investor untuk berinvestasi di saham.

Walaupun secara historis Indeks Saham Syariah Indonesia (ISSI) ini tergolong baru, namun perkembangan ISSI ini sejak diluncurkannya pada tanggal 12 Mei 2011 sampai Mei 2014 bergerak naik. Perkembangan ISSI ini dibandingkan dengan indeks saham syariah yang lain seperti JII, dapat dilihat pada tabel dibawah ini:

Tabel 1

\begin{tabular}{ccc}
$\begin{array}{c}\text { Perbandingan Saham Syariah di Bursa Efek Indonesia } \\
\text { Tahun }\end{array}$ & JII (Milyar) & ISSI (Milyar) \\
\hline 2011 & $\mathrm{Rp} 1.414 .983$ & $\mathrm{Rp} 1.968 .091$ \\
\hline 2012 & $\mathrm{Rp} 1.671 .004$ & $\mathrm{Rp} 2.451334$ \\
\hline 2013 & $\mathrm{Rp} 1.672 .099$ & $\mathrm{Rp} 2.557 .846$ \\
\hline 2014 & $\mathrm{Rp} 1.944 .531$ & $\mathrm{Rp} 2.946 .892$ \\
\hline 2015 & $\mathrm{Rp} 1.737 .290$ & $\mathrm{Rp} 2.600 .850$ \\
\hline 2016 & $\mathrm{Rp} 2.188 .781$ & $\mathrm{Rp} 3.291 .469$ \\
\hline
\end{tabular}

Sumber: Otoritas Jasa Keuangan

Pada tabel 1.1 menunjukkan bahwa dari mulai berdirinya ISSI pada Mei 2011 tercatat sebesar Rp 1.968.091 Milyar hingga tahun 2014 mencapai Rp 2.946.892 Milyar. Peningkatan ISSI ini cukup tinggi dibandingkan dengan JII yang sejak diluncurkan pada tahun 2000 hanya sebesar Rp 1.414.983 Milyar pada tahun 2011, dan sampai tahun 2014 hanya mencapai Rp 1.944.531 Milyar tetap masih dibawah ISSI. Dari mulai dibentuknya ISSI pada tahun 2011, JII maupun ISSI selalu mengalami peningkatan setiap tahunnya, walaupun jika dibandingkan jumlah kenaikan ISSI dengan JII tetap ISSI selalu unggul dengan JII, namun pada tahun 2015 JII dan ISSI mengalami penurunan dari tahun sebelumnya. Untuk JII pada tahun 2015 sebesar Rp 216 
Octavia Setyani: Pengaruh Inflasi dan...

1.737.290 Milyar dan ISSI sebesar Rp 2.600.850 Milyar. Lalu pada tahun 2016, baik JII maupun ISSI kembali mengalami peningkatan, JII sebesar Rp 2.188.781 Milyar dan ISSI sebesar Rp 3.291.469 Milyar.

\begin{tabular}{cccc}
\multicolumn{5}{c}{ Tabel 2 } \\
Perkembangan Inflasi, Nilai Tukar, dan ISSI \\
\hline Tahun & INFLASI (\%) & Nilai Tukar & ISSI (Milyar) \\
\hline 2011 & $3,79 \%$ & Rp $8.779,49$ & Rp 1.968.091,37 \\
\hline 2012 & $4,30 \%$ & Rp 9.380,39 & Rp 2.451.334,37 \\
\hline 2013 & $8,38 \%$ & Rp $10.451,37$ & Rp 2.557.846,77 \\
\hline 2014 & $8,36 \%$ & Rp 11.878,30 & Rp 2.946.892,79 \\
\hline 2015 & $3,35 \%$ & Rp 13.391,97 & Rp 2.600.850,72 \\
\hline 2016 & $3,02 \%$ & Rp 13.307,38 & Rp 3.291.469,29 \\
\hline
\end{tabular}

Sumber: Bank Indonesia, Otoritas Jasa Keuangan

Dilihat dari tabel 1.2 diatas, inflasi mengalami fluktuasi setiap tahunnya. Inflasi tertinggi terjadi pada tahun 2013 sebesar 8,38\% sementara inflasi terendah terjadi pada tahun 2016 sebesar 3,02\%. Tingkat inflasi yang tidak terkendali menyebabkan harga-harga akan terus mengalami peningkatan secara umum. Sementara pengaruhnya terhadap saham di pasar modal ialah berkurangnya permintaan sahamsaham karena pendapatan riil masyarakat. Inflasi dapat memiliki dampak positif dan negatif terhadap perekonomian tergantung dari tinggi rendah inflasinya. Tingkat inflasi di Indonesia yang selalu mengalami fluktuasi tidak menutup kemungkinan akan mempengaruhi tingkat investasi di pasar modal Indonesia tidak terkecuali pada Indeks Saham Syariah Indonesia (ISSI).

Nilai tukar mengalami fluktuasi setiap tahunnya. Nilai tukar terbesar terjadi pada tahun 2015 sebesar Rp. 13.391,97, dan terkecil terjadi pada tahun 2011 sebesar Rp. 8.779,49. Nilai tukar akan berpengaruh pada sektor perdagangan yang berkaitan dengan ekspor impor. Dalam pasar modal Indonesia yang tidak dapat terlepas dari perusahaan-perusahaan yang melakukan transaksi perdagangan menggunakan nilai tukar IDR/ USD sehingga perubahan nilai tukar IDR/ USD diperkirakan akan mampu mempengaruhi pergerakan Indeks Saham Syariah Indonesia (ISSI). 
Bersumber dari penjelasan yang telah dijabarkan tersebut, penulis ingin mengetahui variabel apa saja yang mempengaruhi ISSI, dan memfokuskan pada permasalahan:

1. Bagaimanakah pengaruh Inflasi terhadap ISSI?

2. Bagaimanakah pengaruh Nilai Tukar terhadap ISSI?

3. Bagaimanakah pengaruh Inflasi dan Nilai Tukar terhadap ISSI?

\section{Kerangka Pemikiran}

Indeks Saham Syariah Indonesia (ISSI) merupakan indeks saham yang mencerminkan keseluruhan saham syariah yang tercatat di Bursa Efek Indonesia (BEI). Pada saat diluncurkan tanggal 12 Mei 2011, jumlah saham syariah yang tercatat di BEI sebanyak 214 saham. Keberadaan ISSI melengkapi indeks syariah yang sudah ada sebelumnya yaitu Jakarta Islamic Index (JII). Konstituen ISSI adalah keseluruhan saham syariah yang tercatat di BEI dan terdaftar dalam Daftar Efek Syariah (DES) yang direview setiap enam bulan sekali (Mei dan November) dan dipublikasikan pada awal bulan berikutnya. Konstituen ISSI juga dilakukan penyesuaian apabila ada saham syariah yang baru tercatat atau dihapuskan dalam DES. ${ }^{5}$

Terdapat beberapa faktor-faktor penting yang mampu mempengaruhi indeks syariah yaitu variabel makroekonomi dan moneter, seperti Sertifikat Bank Indonesia Syariah (SBIS), Jumlah Uang Beredar (JUB), inflasi, nilai tukar, dan pertumbuhan GDP. Dalam penelitian ini menggunakan variabel inflasi dan nilai tukar yang diperkirakan mampu mempengaruhi pergerakan Indeks Saham Syariah Indonesia (ISSI).

Inflasi adalah kecendrungan harga-harga umum barang dan jasa meningkat secara terus-menerus dalam kurun waktu tertentu. Peningkatan inflasi secara relatif merupakan sinyal negatif bagi pemodal di pasar modal. Kenaikan inflasi menyebabkan menurunnya daya beli masyarakat terhadap barang dan jasa yang dihasilkan perusahaan. Hal ini mengakibatkan tingkat penjualan mengalami penurunan, yang pada akhirnya menurunkan tingkat laba yang diperoleh perusahaan. Penurunan laba perusahaan ini juga terjadi karena inflasi meningkatkan pendapatan 
Octavia Setyani: Pengaruh Inflasi dan...

dan biaya perusahaan. Jika peningkatan biaya produksi lebih tinggi dari peningkatan harga yang dapat dinikmati oleh perusahaan maka profitabilitas perusahaan akan turun. Penurunan laba suatu perusahaan menurunkan minat investor untuk menanamkan modalnya di perusahaan tersebut. Bagi perusahaan yang sahamnya tercatat di bursa efek, turunnya minat investor tercermin pada turunnya harga saham tersebut. Turunnya harga saham suatu perusahaan yang tercatat di bursa efek ini akan mendorong penurunan IHSG di BEI. ${ }^{6}$

Inflasi yang semakin tinggi menjadi sinyal negatif bagi para investor yang berinvestasi di pasar modal. Investor akan cenderung melepas sahamnya jika terjadi peningkatan inflasi, terlebih pada saat terjadi inflasi yang tidak terkendali (hyperinflation). Hal ini karena peningkatan inflasi yang tinggi menyebabkan kenaikan risiko investasi pada saham. Di samping itu juga diiringi oleh pesimisme investor tentang kemampuan dari modal dalam menghasilkan laba di masa kini dan masa mendatang. Kecendrungan para investor untuk melepas sahamnya akan menyebabkan harga saham tersebut turun. Terjadinya penurunan harga saham ini akan tercermin pada indeks harga saham. ${ }^{7}$

Hubungan antara nilai tukar rupiah terhadap mata uang asing dengan harga saham diantaranya dapat dilihat melalui pendekatan pasar barang (good market approach), dimana perubahan kurs akan mempengaruhi suatu perusahaan, kemudian akan mempengaruhi pendapatan perusahaan atau struktur cost of fund-nya. Hal tersebut akan berpengaruh pada harga saham suatu perusahaan. Pada saat kurs rupiah terdepresiasi maka biaya bahan baku impor atau produk yang memiliki kaitan dengan produk impor akan mengalami kenaikan. Kejadian ini menyebabkan biaya produksi meningkat dan laba perusahaan menjadi turun sehingga tingkat dividen yang dapat dibagikan dan return yang ditawarkan akan menurun pula. Penurunan return yang ditawarkan akan mengakibatkan permintaan terhadap saham tersebut berkurang sehingga harga saham menjadi turun. Kondisi seperti ini akan mendorong investor untuk melepas sahamnya sehingga berdampak pada menurunnya harga saham yang kemudian penurunan tersebut akan tercermin pada indeks harga saham, begitupun sebaliknya. ${ }^{8}$ 
Islamiconomic: Jurnal Ekonomi Islam Vol.8 No.2 Juli - Desember 2017

Kurs rupiah adalah nilai tukar sejumlah rupiah yang diperlukan untuk membeli satu US\$. Jika nilai tukar rupiah terhadap US\$ menguat, ini berarti nilai tukar sejumlah rupiah yang diperlukan untuk membeli satu US\$ akan rendah maka harga saham semakin tinggi. Sebaliknya jika nilai tukar rupiah terhadap US\$ melemah, ini berarti nilai tukar sejumlah rupiah yang diperlukan untuk membeli satu US\$ akan tinggi maka harga saham semakin rendah.

Jika permintaan kurs rupiah relatif lebih sedikit daripada supply rupiah maka kurs rupiah ini akan terdepresiasi dan juga sebaliknya. Bagi investor depresiasi rupiah terhadap dollar menandakan bahwa prospek perekonomian Indonesia suram. Sebab depresiasi rupiah dapat terjadi apabila faktor fundamental perekonomian Indonesia tidaklah kuat. Hal ini tentunya menambah risiko bagi investor apabila hendak berinvestasi di bursa saham Indonesia. Investor tentunya akan menghindari risiko sehingga investor akan cenderung melakukan aksi jual dan menunggu hingga situasi perekonomian dirasakan membaik. Aksi jual yang dilakukan investor ini akan mendorong penurunan indeks harga saham di BEI. ${ }^{9}$

Selanjutnya investasi yang tertanam di suatu negara ini juga akan menjadi stimulus dalam tumbuh dan berkembangnya perekonomian suatu negara. Diharapkan ISSI yang merupakan salah satu dari sekian banyak alat investasi dapat menyumbangkan perannya untuk memberikan dampak yang besar dalam meningkatkan pertumbuhan ekonomi Indonesia. Dari uraian diatas, kerangka pemikiran dapat digambarkan sebagai berikut:

\section{Gambar 1}

\section{Kerangka Pemikiran}

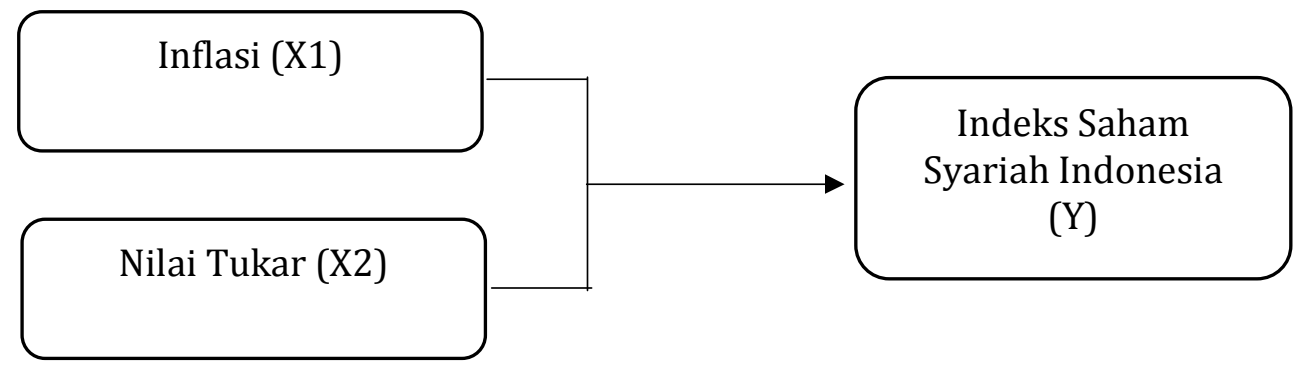


Octavia Setyani: Pengaruh Inflasi dan...

\section{Indeks Saham Syariah Indonesia (ISSI)}

Indeks Saham Syariah Indonesia (ISSI) merupakan indeks saham yang mencerminkan keseluruhan saham syariah yang tercatat di Bursa Efek Indonesia (BEI). Konstituen ISSI adalah keseluruhan saham syariah yang tercatat di BEI dan terdaftar dalam Daftar Efek Syariah (DES).

ISSI diluncurkan pada tanggal 12 Mei 2011 dan konstituennya direview setiap enam bulan sekali pada bulan Mei dan November serta efektif pada awal bulan berikutnya. Namun demikian, tidak seperti indeks-indeks lain di BEI yang perubahan konstituennya dilakukan secara terjadwal setiap enam bulan sekali, konstituen ISSI dapat dilakukan penyesuaian setiap saat apabila ada saham syariah yang baru tercatat dari Dewan Efek Syariah.

Selama ini investasi syariah di pasar modal Indonesia identik dengan Jakarta Islamic Index (JII) yang hanya terdiri dari 30 saham syariah yang tercatat di Bursa Efek Indonesia (BEI). Padahal efek syariah yang terdapat di pasar modal Indonesia bukan hanya 30 saham syariah yang menjadi konstituen JII saja tetapi terdiri dari berbagai macam jenis efek selain saham syariah, yaitu obligasi syariah dan reksadana syariah.

\section{Inflasi}

Yang dimaksud dengan inflasi adalah proses kenaikan harga-harga umum secara terus-menerus. Akibat dari inflasi secara umum adalah menurunnya daya beli masyarakat karena secara ritel tingkat pendapatannya juga menurun. Jadi, misalkan besarnya inflasi pada tahun yang bersangkutan naik sebesar 5\% sementara pendapatan tetap, maka itu berarti secara ritel pendapatan mengalami penurunan sebesar 5\% yang akibatnya secara relatif akan menurunkan daya beli sebesar 5\% juga. ${ }^{10}$

Menurut Pratama Rahardja dan Mandala Manurung, inflasi adalah kenaikan harga barang-barang yang bersifat umum dan terus menerus. Dari definisi ini ada tiga komponen yang harus dipenuhi agar dapat dikatakan telah terjadi inflasi, yaitu kenaikan harga, bersifat umum, dan berlangsung terus-menerus. ${ }^{11}$ 
Islamiconomic: Jurnal Ekonomi Islam

Vol.8 No.2 Juli - Desember 2017

Secara umum, inflasi rendah masih dapat diterima, bahkan dalam tingkat tertentu bisa mendorong perkembangan ekonomi. Misalnya Indonesia mengalami inflasi 3\%. Dengan inflasi tersebut, berarti harga barang naik sekitar 3\% juga. Keadaan tersebut mendorong produsen untuk meningkatkan kapasitas produksi mereka (sesuai hukum penawaran, apabila harga barang/ jasa naik maka produsen akan menambah jumlah barang/ jasa yang ditawarkan). Dengan harga yang semakin tinggi, menjadikan pendapatan produsen meningkat. Selain itu peningkatan biaya produksi tidak secepat kenaikan harga. Dengan demikian, kenaikan harga produk berarti juga mendorong peningkatan laba produsen. Di sisi lain, inflasi yang rendah menyebabkan daya beli masyarakat menurun, tetapi tidak signifikan. Mungkin sebagian penduduk tidak merasakan kenaikan harga. Akibatnya mereka tidak mengurangi belanja/ konsumsinya.

Sebaliknya, inflasi yang terlalu tinggi dapat mengurangi pertumbuhan ekonomi. Karena dari sisi permintaan menyebabkan daya beli masyarakat menurun drastis, sehingga berdampak pada berkurangnya konsumsi masyarakat. Turunnya permintaan akan direspon oleh produsen dengan mengurangi jumlah produksi. Pada akhirnya roda perekonomian ikut terpengaruh menjadi melambat dan PDB mengalami penurunan. ${ }^{12}$

\section{Nilai Tukar}

Exchange rates (nilai tukar uang) atau yang dikenal dengan kurs mata uang adalah catatan (quotation) harga pasar dari mata uang asing (foreign currency) dalam harga mata uang domestik (domestic currency) atau resiprokalnya, yaitu harga mata uang domestik dalam mata uang asing. Nilai tukar uang merepresentasikan tingkat harga pertukaran dari satu mata uang ke mata uang lainnya dan digunakan dalam berbagai transaksi, antara lain transaksi perdagangan internasional, turisme, investasi internasional ataupun aliran uang jangka pendek antarnegara yang melewati batas-batas geografis ataupun batas-batas hukum. ${ }^{13}$

Nilai tukar atau kurs (foreign exchange rate) dapat didefinisikan sebagai harga mata uang suatu negara relatif terhadap mata uang negara lain. Karena nilai tukar ini mencakup dua mata uang, maka titik keseimbangan ditentukan oleh sisi penawaran 
Octavia Setyani: Pengaruh Inflasi dan...

dan permintaan dari kedua mata uang tersebut, atau dengan kata lain nilai tukar adalah sejumlah uang dari suatu mata uang tertentu yang dipertukarkan dengan satu unit mata uang negara lain. ${ }^{14}$

Jika mata uang suatu negara nilainya meningkat, maka disebut mengalami apresiasi. Sedangkan jika terjadi sebaliknya, maka disebut mengalami depresiasi. ${ }^{15}$

\section{Hipotesis Penelitian}

Hipotesis adalah jawaban atau dugaan sementara yang harus diuji lagi kebenarannya. ${ }^{16}$ Hipotesis penelitian ini adalah:

$$
\begin{aligned}
& \mathrm{H}_{0} \text { : Inflasi tidak berpengaruh terhadap ISSI } \\
& \mathrm{H}_{1} \text { : Inflasi berpengaruh terhadap ISSI } \\
& \mathrm{H}_{0} \text { : Nilai Tukar tidak berpengaruh terhadap ISSI } \\
& \mathrm{H}_{1} \text { : Nilai Tukar berpengaruh terhadap ISSI }
\end{aligned}
$$

\section{Tempat dan Waktu Penelitian}

Penelitian ini dilakukan di Bursa Efek Indonesia (Indonesian Stock Exchange) yang beralamat di Jl. Jenderal Sudirman Kav. 52-53, Senayan, Kebayoran Baru, Jakarta Selatan 12190, Indonesia. Telp: 021-5150515. Fax: 021-5150330. Email: callcenter@idx.co.id. Website: www.idx.co.id.

Penelitian ini dilakukan pada Januari sampai Februari 2017 dengan tahun pengamatan dari Mei 2011 sampai Mei 2016 untuk memperoleh data-data yang menunjukkan gambaran tentang pengaruh inflasi dan nilai tukar terhadap Indeks Saham Syariah Indonesia (ISSI).

\section{Jenis dan Sumber Data}

Jenis data yang digunakan dalam penelitian ini adalah data sekunder, yaitu data yang diperoleh dari sumber kedua atau sumber sekunder dari data yang dibutuhkan. Dengan kata lain, data penelitian ini diperoleh peneliti secara tidak langsung, melalui media perantara. ${ }^{17}$ Sumber data yang digunakan dalam penelitian ini berasal dari website Bank Indonesia, Badan Pusat Statistik, dan Otoritas Jasa Keuangan. 


\section{Populasi dan Sampel}

Populasi yang digunakan dalam penelitian ini adalah pergerakan Indeks Saham Syariah Indonesia (ISSI), inflasi, dan nilai tukar selama periode Mei 2011 sampai Mei 2016. Adapun teknik pengambilan sampel yang digunakan dalam penelitian ini adalah nonprobability sampling. Yaitu dengan menggunakan sampling jenuh adalah teknik penentuan sampel bila semua anggota populasi dgunakan sebagai sampel. ${ }^{18}$

\section{Teknik Analisis Data}

1. Statistik Deskriptif bertujuan untuk menguji hipotesis dari penelitian yang bersifat deskriptif. Statistik deskriptif juga berusaha untuk menggambarkan berbagai karakteristik data yang berasal dari suatu sampel.

2. Uji Asumsi Klasik

a. Uji Normalitas bertujuan untuk menguji apakah dalam model regresi, variabel pengganggu atau residual memiliki distribusi normal. ${ }^{19}$ Model regresi yang baik adalah memiliki distribusi data normal atau mendekati normal. Distribusi normal akan membentuk satu garis lurus diagonal, dan ploting data akan dibandingkan dengan garis diagonal. Jika distribusi data adalah normal, maka garis yang menghubungkan data sesungguhnya akan mengikuti garis diagonalnya. Data akan bagus apabila bebas dari bias dan berdistribusi normal.

b. Uji Heteroskedastisitas bertujuan menguji apakah dalam model regresi terjadi ketidaksamaan variance dari residual satu pengamatan ke pengamatan yang lain. Jika variance dari residual satu pengamatan ke pengamatan yang lain tetap, maka disebut homoskedastisitas, dan jika berbeda disebut heteroskedastisitas. Model regresi yang baik adalah yang homoskedastisitas atau tidak terjadi heteroskedastisitas. ${ }^{20}$

c. Uji Autokorelasi bertujuan menguji apakah dalam model regresi linear ada korelasi antara kesalahan pengganggu pada periode $\mathrm{t}$ dengan kesalahan pengganggu pada periode t-1 (sebelumnya). Jika terjadi korelasi, maka 
Octavia Setyani: Pengaruh Inflasi dan...

dinamakan ada problem autokorelasi. Autokorelasi muncul karena observasi yang berurutan sepanjang waktu berkaitan satu sama lainnya. ${ }^{21}$

d. Uji Multikolinearitas bertujuan untuk menguji apakah model regresi ditemukan adanya korelasi antar variabel bebas (independen). Model regresi yang baik seharusnya tidak terjadi korelasi diantara variabel independen. ${ }^{22}$

3. Analisis Regresi Berganda digunakan untuk memprediksikan seberapa jauh perubahan nilai variabel dependen, bila nilai variabel independen dimanipulasi/ dirubah-rubah atau dinaik-turunkan. ${ }^{23}$ Analisis regresi berganda digunakan untuk menguji pengaruh inflasi, dan nilai tukar terhadap Indeks Saham Syariah Indonesia. Seberapa besar variabel independen mempengaruhi variabel dependen dihitung dengan menggunakan persamaan garis regresi berganda berikut:

$$
\mathbf{Y}=\mathbf{a}+\mathbf{b}_{1} \mathbf{X}_{1}+\mathbf{b}_{2} \mathbf{X}_{2}+\mathbf{e}
$$

Keterangan:

$$
\begin{array}{ll}
\mathrm{Y} & =\text { Indeks Saham Syariah Indonesia (ISSI) } \\
\mathrm{a} & =\text { Konstanta } \\
\mathrm{b} & =\text { Koefisien Garis Regresi } \\
\mathrm{X}_{1} & =\text { Inflasi } \\
\mathrm{X}_{2} & =\text { Nilai Tukar } \\
\mathrm{e} & =\text { Error }
\end{array}
$$

4. Uji Hipotesis

a. Uji Parsial (Uji t) pada dasarnya menunjukkan seberapa jauh pengaruh satu variabel independen terhadap variabel dependen dengan menganggap variabel independen lainnya konstan. Untuk mengetahui nilai t statistik tabel ditentukan tingkat signifikansi 5\% dengan derajat kebebasan, yaitu $\mathrm{df}=(\mathrm{n}-\mathrm{k}-$ 1), dimana $\mathrm{n}=$ jumlah observasi, dan $\mathrm{k}=$ jumlah variabel.

b. Uji Simultan (Uji F) pada dasarnya menunjukkan apakah semua variabel independen yang dimasukkan dalam model mempunyai pengaruh secara bersama-sama atau simultan terhadap variabel dependen. ${ }^{24} \mathrm{Uji}$ ini digunakan untuk menguji kelayakan model goodness of fit. Tingkat signifikansi yang 
Islamiconomic: Jurnal Ekonomi Islam Vol.8 No.2 Juli - Desember 2017

digunakan sebesar $5 \%$ dengan dengan $\mathrm{V}_{1}$ (Numerator) = jumlah variabel - 1 dan $V_{2}$ (Denumerator) = jumlah sampel - jumlah variabel..$^{25}$

c. Koefisien Korelasi menunjukkan kemampuan hubungan antara variabel independen dengan variabel dependen. Angka koefisien korelasi yang dihasilkan dalam uji ini berguna untuk menunjukkan kuat lemahnya hubungan antara variabel independen dengan variabel dependen.

d. Koefisien Determinasi digunakan untuk mengukur seberapa jauh kemampuan model dalam menerangkan variabel dependen. ${ }^{26}$ Nilai koefisien determinasi adalah antara 0 sampai 1 . Nilai $\mathrm{R}^{2}$ yang kecil berarti kemampuan variabelvariabel independen dalam menerangkan variabel dependen sangat terbatas. Nilai yang mendekati 1 berarti variabel independen memberikan hampir semua informasi yang dibutuhkan untuk memprediksi variasi variabel dependen.

\section{Analisis Deskriptif}

Tabel 3

Statistik Deskriptif

Descriptive Statistics

\begin{tabular}{|l|r|r|r|r|r|}
\hline & $\mathrm{N}$ & $\begin{array}{c}\text { Minimu } \\
\mathrm{m}\end{array}$ & $\begin{array}{c}\text { Maximu } \\
\mathrm{m}\end{array}$ & \multicolumn{1}{c|}{ Mean } & $\begin{array}{c}\text { Std. } \\
\text { Deviation }\end{array}$ \\
\hline INFLASI & 60 & .0333 & .0879 & .056784 & .0160135 \\
KURS & 60 & 8532.00 & 14396.10 & 11120.7190 & 1808.87031 \\
ISSI & 60 & 1512915 & 3068467 & 2527652.34 & 408655.883 \\
Valid N & 60 & & & & \\
(listwise) & & & & & \\
\hline
\end{tabular}

Berdasarkan data diatas, terlihat bahwa variabel inflasi yang menjadi sampel berkisar antara 0,0333 sampai dengan 0,0879 dengan rata-rata sebesar 0,056784. Standar deviasi variabel inflasi yaitu 0,0160135. Variabel nilai tukar berkisar antara Rp. 8.532,00 sampai dengan Rp. 14.396,10 dengan rata-rata sebesar Rp. 11.120,7190. Standar deviasi variabel nilai tukar sebesar Rp. 1.808,87031. Variabel ISSI berkisar antara Rp. 1.512.915 sampai dengan Rp. 3.068.467 dengan rata-rata sebesar Rp. 2.527.652,34. Standar deviasi variabel ISSI sebesar Rp. 408.655,883. 


\section{Uji Asumsi Klasik}

Uji Normalitas

\section{Gambar 2 \\ Uji Normalitas}

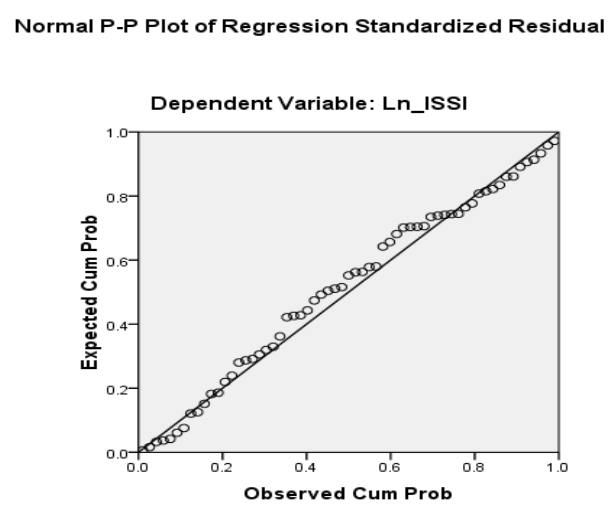

Dari Grafik P-P Plot diatas terlihat bahwa sebaran data dalam penelitian ini memiliki penyebaran dan distribusi yang normal, karena data memusat pada garis diagonal P-P Plot. Maka dapat dikatakan bahwa data penelitian ini memiliki penyebaran dan terdistribusi normal. Untuk menegaskan hasil uji normalitas diatas maka peneliti melakukan uji Kolmogorov-Smirnov dengan hasil sebagai berikut:

Tabel 4

One Sampel Kolmogorov-Smirnov Test One-Sample Kolmogorov-Smirnov Test

\begin{tabular}{|ll|r|}
\hline & & $\begin{array}{r}\text { Unstandardi } \\
\text { zed Residual }\end{array}$ \\
\hline $\mathrm{N}$ & & 61 \\
Normal Parameters & & Mean \\
& Std. Deviation & .0000000 \\
Most Extreme & Absolute & .12493803 \\
Differences & Positive & .082 \\
& Negative & -.082 \\
Kolmogorov-Smirnov Z & .638 \\
Asymp. Sig. (2-tailed) & .811 \\
\hline
\end{tabular}

a. Test distribution is Normal. 
Berdasarkan tabel 4 diatas, hasil Kolmogorov-Smirnov menunjukkan nilai Asymp. Sig memiliki nilai lebih besar dari 0,05. Hal ini menunjukkan bahwa data pada penelitian ini terdistribusi normal dan model regresi tersebut layak dipakai untuk memprediksi variabel dependen yaitu ISSI berdasarkan masukan variabel independen yaitu inflasi dan nilai tukar.

\section{Uji Heteroskedastisitas}

Gambar 3

Uji Heteroskedastisitas

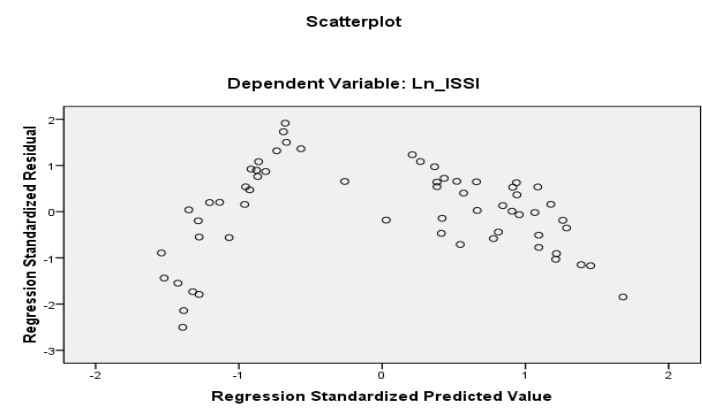

Dari gambar diatas (scatter plot) terlihat tidak ada pola yang jelas serta titiktitik menyebar diatas dan dibawah angka 0 pada sumbu $Y$, maka dapat disimpulkan tidak terjadi heteroskedastisitas.

\section{Uji Autokorelasi}

\section{Tabel 5}

Uji Autokorelasi

Model Summaryb

\begin{tabular}{|l|c|r|r|r|r|}
\hline Model & $\mathrm{R}$ & R Square & $\begin{array}{c}\text { Adjusted R } \\
\text { Square }\end{array}$ & $\begin{array}{c}\text { Std. Error of } \\
\text { the Estimate }\end{array}$ & $\begin{array}{c}\text { Durbin- } \\
\text { Watson }\end{array}$ \\
\hline 1 & $.252^{\mathrm{a}}$ & .064 & .031 & .0441727 & 1.860 \\
\hline
\end{tabular}

a. Predictors: (Constant), Ln_KURS, Ln_INFLASI

b. Dependent Variable: Ln_ISSI

Berdasarkan hasil uji autokorelasi, nilai DW hitung sebesar 1,860. Diperoleh nilai dalam tabel DW untuk "k=2" dan "N=60" adalah nilai dl (batas bawah) sebesar 1,5144 dan nilai du (batas atas) sebesar 1,6518. Berdasarkan pedoman uji statistik Durbin 
Octavia Setyani: Pengaruh Inflasi dan...

Watson, maka dapat dilihat bahwa nilai DW hitung terletak diantara $(\mathrm{du}<\mathrm{d}<4$-du), yaitu sebesar $1,6518<1,860<2,3482$. Maka dapat disimpulkan bahwa data yang digunakan tidak ada autokorelasi.

\section{Uji Multikolinearitas}

Tabel 6

Uji Multikolinearitas

Coefficients ${ }^{\mathbf{a}}$

\begin{tabular}{|c|c|c|c|c|c|}
\hline \multirow[b]{2}{*}{ Model } & \multicolumn{2}{|c|}{$\begin{array}{l}\text { Unstandardized } \\
\text { Coefficients }\end{array}$} & \multirow{2}{*}{$\begin{array}{c}\begin{array}{c}\text { Standardized } \\
\text { Coefficients }\end{array} \\
\text { Beta }\end{array}$} & \multicolumn{2}{|c|}{$\begin{array}{l}\text { Collinearity } \\
\text { Statistics }\end{array}$} \\
\hline & B & $\begin{array}{l}\text { Std. } \\
\text { Error }\end{array}$ & & $\begin{array}{c}\text { Toleranc } \\
\mathrm{e}\end{array}$ & VIF \\
\hline $\begin{array}{ll}1 & \text { (Constant } \\
& \text { ) }\end{array}$ & 1.832 & .236 & & & \\
\hline $\begin{array}{l}\text { Ln_INFLA } \\
\text { SI }\end{array}$ & -.049 & .045 & -.142 & 986 & 1.014 \\
\hline Ln_KURS & -.362 & .243 & -.193 & .986 & 1.014 \\
\hline
\end{tabular}

a. Dependent Variable:

Ln_ISSI

Berdasarkan tabel 4.5 diatas dapat terlihat bahwa nilai VIF semua variabel independen kurang dari 10 dan nilai Tolerance semua variabel independen lebih dari 0,10. Nilai VIF untuk variabel inflasi sebesar 1,014 dengan nilai Tolerance sebesar 0,986. Nilai VIF untuk variabel nilai tukar sebesar 1,014 dengan nilai Tolerance sebesar 0,986.

Dengan demikian dapat disimpulkan model persamaan regresi tidak terdapat multikolinearitas atau dapat dikatakan bebas dari multikolinearitas dan data dapat digunakan untuk penelitian. 


\section{Analisis Regresi Linier Berganda}

\section{Tabel 7 \\ Persamaan Regresi \\ Coefficients ${ }^{\mathrm{a}}$}

\begin{tabular}{|c|c|c|c|c|c|}
\hline \multirow[b]{2}{*}{ Model } & \multicolumn{2}{|c|}{$\begin{array}{l}\text { Unstandardized } \\
\text { Coefficients }\end{array}$} & \multirow{2}{*}{ 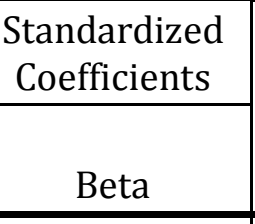 } & \multirow[b]{2}{*}{$\mathrm{t}$} & \multirow[b]{2}{*}{ Sig. } \\
\hline & B & $\begin{array}{l}\text { Std. } \\
\text { Error }\end{array}$ & & & \\
\hline $1 \quad \begin{array}{l}\text { (Constant } \\
\quad \quad)\end{array}$ & 1.832 & .236 & & 7.754 & .000 \\
\hline $\begin{array}{l}\text { Ln_INFLA } \\
\text { SI }\end{array}$ & -.049 & .045 & -.142 & -1.097 & .277 \\
\hline Ln_KURS & -.362 & .243 & -.193 & -1.493 & .141 \\
\hline
\end{tabular}

a. Dependent Variable:

Ln_ISSI

Dari tabel diperoleh hasil regresi linier berganda yaitu sebagai berikut:

$$
\mathrm{Y}=1,832-0,049 \mathrm{X}_{1}-0,362 \mathrm{X}_{2}+\mathrm{e}
$$

Berdasarkan fungsi persamaan regresi linear berganda diatas maka dapat dijelaskan sebagai berikut:

a. Konstanta (nilai mutlak Y) apabila inflasi dan nilai tukar sama dengan nol, maka Indeks Saham Syariah sebesar 1,832.

b. Koefisien regresi $X_{1}$ (Inflasi) sebesar -0,049 artinya apabila inflasi naik sebesar satu satuan kali akan menyebabkan penurunan Indeks Saham Syariah Indonesia atau berpengaruh negatif sebesar 0,049; bila variabel lain konstan.

c. Koefisien regresi $\mathrm{X}_{2}$ (Nilai Tukar) sebesar $-0,362$ artinya apabila nilai tukar naik sebesar satu satuan kali akan menyebabkan penurunan Indeks Saham Syariah Indonesia atau berpengaruh negatif sebesar 0,362; bila variabel lain konstan. 


\section{Uji F (Simultan)}

Tabel 8

Uji F (Simultan)

ANOVAb

\begin{tabular}{|c|c|c|c|c|c|c|}
\hline \multicolumn{2}{|c|}{ Model } & $\begin{array}{c}\text { Sum of } \\
\text { Squares }\end{array}$ & $\mathrm{df}$ & $\begin{array}{c}\text { Mean } \\
\text { Square }\end{array}$ & $\mathrm{F}$ & Sig. \\
\hline \multirow[t]{3}{*}{1} & Regression & .008 & 2 & .004 & 1.934 & $.154^{\circ}$ \\
\hline & Residual & .111 & 57 & .002 & & \\
\hline & Total & .119 & 59 & & & \\
\hline
\end{tabular}

a. Predictors: (Constant), Ln_KURS,

Ln_INFLASI

b. Dependent Variable: Ln_ISSI

Dari perhitungan diatas dapat dilihat bahwa nilai $\mathrm{F}_{\text {hitung }}$ lebih kecil dari $\mathrm{F}$ tabel $(1,934<3,16)$ maka Ho diterima. Dan dapat dilihat bahwa nilai signifikansi lebih besar dari 0,05 (0,154>0,05) maka Ho diterima. Artinya secara simultan variabel inflasi dan nilai tukar tidak berpengaruh signifikan terhadap Indeks Saham Syariah Indonesia.

\section{Uji t (Parsial)}

\section{Tabel 9 \\ Uji t (Parsial)}

Coefficients $^{\mathbf{a}}$

\begin{tabular}{|c|c|c|c|c|c|}
\hline \multirow[b]{2}{*}{ Model } & \multicolumn{2}{|c|}{$\begin{array}{l}\text { Unstandardized } \\
\text { Coefficients }\end{array}$} & \multirow{2}{*}{$\begin{array}{c}\text { Standardized } \\
\text { Coefficients } \\
\text { Beta } \\
\end{array}$} & \multirow[b]{2}{*}{$\mathrm{t}$} & \multirow[b]{2}{*}{ Sig. } \\
\hline & B & $\begin{array}{l}\text { Std. } \\
\text { Error }\end{array}$ & & & \\
\hline $\begin{array}{ll}1 & \text { Constant } \\
& \text { ) }\end{array}$ & 1.832 & .236 & & 7.754 & .000 \\
\hline $\begin{array}{l}\text { Ln_INFLA } \\
\text { SI }\end{array}$ & -.049 & .045 & -.142 & -1.097 & .277 \\
\hline Ln_KURS & -.362 & .243 & -.193 & -1.493 & .141 \\
\hline
\end{tabular}

a. Dependent Variable:

Ln_ISSI 
Dari perhitungan diatas dapat dilihat bahwa nilai $t$ hitung variabel inflasi lebih kecil dari $t_{\text {tabel }}(-1,097<2,002)$ maka Ho diterima. Dan nilai $t_{\text {hitung variabel nilai tukar }}$ lebih kecil dari $t$ tabel $(-1,493<2,002)$ maka Ho diterima.

Sedangkan nilai signifikansi variabel inflasi lebih besar dari 0,05 $(0,277>0,05)$ maka Ho diterima. Dan nilai signifikansi variabel nilai tukar lebih besar dari 0,05 $(0,141>0,05)$ maka Ho diterima.

Dengan demikian dapat disimpulkan bahwa secara parsial variabel inflasi tidak berpengaruh signifikan terhadap Indeks Saham Syariah Indonesia, dan secara parsial variabel nilai tukar tidak berpengaruh signifikan terhadap Indeks Saham Syariah Indonesia.

\section{Koefisien Korelasi}

Tabel 10

\section{Koefisien Korelasi}

Model Summaryb

\begin{tabular}{|l|c|r|r|r|r|}
\hline Model & $\mathrm{R}$ & R Square & $\begin{array}{c}\text { Adjusted R } \\
\text { Square }\end{array}$ & $\begin{array}{c}\text { Std. Error of } \\
\text { the Estimate }\end{array}$ & $\begin{array}{c}\text { Durbin- } \\
\text { Watson }\end{array}$ \\
\hline 1 & $.252^{\mathrm{a}}$ & .064 & .031 & .0441727 & 1.860 \\
\hline
\end{tabular}

a. Predictors: (Constant), Ln_KURS, Ln_INFLASI

b. Dependent Variable: Ln_ISSI

Berdasarkan tabel diatas, diperoleh koefisien korelasi sebesar 0,252 terletak pada interval koefisien 0,20 - 0,399 yang berarti tingkat hubungan antara inflasi dan nilai tukar dengan Indeks Saham Syariah Indonesia adalah rendah. 


\section{Koefisien Determinasi}

Koefisien determinasi pada intinya mengukur seberapa jauh kemampuan model dalam menerangkan variasi variabel dependen. Nilai $\mathrm{R}^{2}$ terletak antara 0 sampai dengan $1\left(0 \leq \mathrm{R}^{2} \leq 1\right)$. Tujuan menghitung koefisien determinasi adalah untuk mengetahui pengaruh variabel independen terhadap variabel dependen. Jika dalam proses mendapatkan nilai $\mathrm{R}^{2}$ yang tinggi adalah baik, tetapi jika nilai $\mathrm{R}^{2}$ rendah tidak berarti model regresi tidak baik. Nilai $\mathrm{R}^{2}$ pada penelitian ini dapat dilihat pada tabel sebagai berikut:

\begin{tabular}{|c|c|c|c|c|c|}
\hline & & $\begin{array}{r}\text { Koef } \\
\mathbf{M}\end{array}$ & $\begin{array}{c}\text { Tabel } 11 \\
\text { isien Determ } \\
\text { odel Summar }\end{array}$ & $\begin{array}{l}\text { inasi } \\
y^{b}\end{array}$ & \\
\hline Model & $\mathrm{R}$ & R Square & $\begin{array}{l}\text { Adjusted R } \\
\text { Square }\end{array}$ & $\begin{array}{l}\text { Std. Error of } \\
\text { the Estimate }\end{array}$ & $\begin{array}{l}\text { Durbin- } \\
\text { Watson }\end{array}$ \\
\hline 1 & $.252^{\mathrm{a}}$ & .064 & .031 & .0441727 & 1.860 \\
\hline
\end{tabular}

Nilai koefisien determinasi $\left(R^{2}\right)$ sebesar 0,064 . Hal ini berarti variabel inflasi dan nilai tukar dapat menjelaskan pengaruhnya terhadap Indeks Saham Syariah Indonesia yaitu sebesar 6,4\%. Sedangkan sisanya yaitu sebesar 100\% - 6,4\% = 93,6\% dijelaskan oleh faktor-faktor lainnya. Seperti beberapa variabel makroekonomi dan moneter lainnya, yaitu jumlah uang beredar, ekspor, impor, dan faktor internal lainnya seperti konsisi ekonomi nasional, kondisi politik, keamanan, dan kebijakan pemerintah.

\section{Kesimpulan}

1. Hasil analisis data menunjukkan bahwa variabel inflasi $\left(\mathrm{X}_{1}\right)$ secara parsial tidak berpengaruh signifikan terhadap Indeks Saham Syariah Indonesia. Hal ini dapat dilihat dari nilai $\mathrm{t}$ hitung lebih kecil dari $\mathrm{t}$ tabel, yaitu $(-1,097<2,002)$ serta nilai signifikansi lebih besar dari 0,05, yaitu $(0,277>0,05)$.

2. Hasil analisis data menunjukkan bahwa variabel nilai tukar $\left(\mathrm{X}_{2}\right)$ secara parsial tidak berpengaruh signifikan terhadap Indeks Saham Syariah Indonesia. Hal ini 


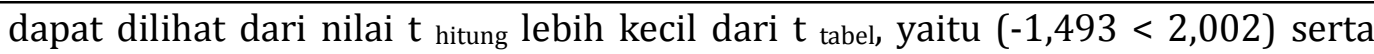
nilai signifikansi lebih besar dari 0,05, yaitu $(0,141>0,05)$.

3. Hasil analisis data menunjukkan bahwa variabel inflasi $\left(\mathrm{X}_{1}\right)$ dan nilai tukar $\left(\mathrm{X}_{2}\right)$ secara simultan tidak berpengaruh signifikan terhadap Indeks Saham Syariah Indonesia. Hal ini dapat dilihat dari nilai $\mathrm{F}_{\text {hitung }}$ lebih kecil dari $\mathrm{F}_{\text {tabel, }}$ yaitu $(1,934$ $<3,16)$ serta nilai signifikansi lebih besar dari 0,05, yaitu $(0,154>0,05)$.

\section{Saran}

1. Bagi pemerintah diharapkan lebih memperhatikan kebijakan mengenai inflasi dan nilai tukar, karena jika kedua variabel tersebut tidak stabil atau selalu berfluktuasi akan memberikan efek buruk bagi investasi di pasar modal Indonesia tidak terkecuali pada Indeks Saham Syariah Indonesia.

2. Bagi praktisi lembaga keuangan dan pihak-pihak lain yang berkepentingan agar lebih mensosialisasikan Indeks Saham Syariah Indonesia, hal ini dimaksudkan untuk memudahkan dan memberikan pilihan lain kepada masyarakat yang ingin menginvestasikan uangnya pada indeks syariah agar tidak salah tempat.

3. Bagi penelitian selanjutnya diharapkan dapat melanjutkan dan memperpanjang periode waktu penelitian serta dapat menggunakan lebih banyak lagi variabelvariabel yang mungkin dapat mempengaruhi Indeks Saham Syariah Indonesia. Sehingga dapat memberikan hasil penelitian yang lebih akurat dan lebih baik.

\section{Daftar Pustaka}

Arif, M. Nur. Lembaga Keuangan Syariah: Suatu Kajian Teoretis Praktis. Bandung: Pustaka Setia. 2012.

Boediono. Seri Sinopsis Pengantar Ilmu Ekonomi No. 2 Ekonomi Makro Edisi Keempat. Yogyakarta: BPFE. 2014.

Darmadji, Tjipto. Pasar Modal di Indonesia. Jakarta: Salemba Empat. 2000.

Departemen Agama RI. Al Qur'an Tajwid dan Terjemahnya. Bandung: PT Syaamil Cipta Media. 2006

Ekananda, Mahyus. Ekonomi Internasional. Jakarta: Erlangga. 2014.

Ghozali, Imam. Aplikasi Analisis Multivariate dengan Program IBM SPSS 23. Semarang: Badan Penerbit Universitas Diponegoro. 2016.

Huda, Nurul dan Mustafa Edwin N. Investasi pada Pasar Modal Syariah. Jakarta: Kencana. 2008. 
Octavia Setyani: Pengaruh Inflasi dan...

Ibrahim, Zaini. Pengantar Ekonomi Makro Edisi Revisi . Serang: LP2M IAIN Sultan Maulana Hasanuddin Banten. 2013.

Karim, Adiwarman. Ekonomi Islam: Suatu Kajian Ekonomi Makro. Jakarta: IIIT Indonesia. 2002.

Kasmir. Bank dan Lembaga Keuangan Lainnya. Jakarta: Rajawali Pers. 2013.

Krugman, Paul. R. Ekonomi Internasional: Teori dan Kebijakan Edisi Kedua . Jakarta: Raja Grafindo Persada. 2005.

Kuncoro, Mudrajat. Metode Riset untuk Bisnis dan Ekonomi. Jakarta: Erlangga. 2009.

Manan, Abdul. Aspek Hukum dalam Penyelenggaraan Investasi di Pasar Modal Syariah Indonesia . Jakarta: Kencana . 2009.

Mankiw, N. Gregory. Makroekonomi . Jakarta: Erlangga. 2006.

Mankiw, N. Gregory. Pengantar Ekonomi Makro Edisi Asia. Jakarta: Salemba Empat. 2014.

Murni, Asfia. Ekonomika Makro. Bandung: PT Refika Aditama. 2006.

Nachrowi, Djalal Nachrowi dan Hardius Usman. Pendekatan Populer dan Praktis Ekonometrika untuk Analisis Ekonomi dan Keuangan. Jakarta: Lembaga Penerbit Fakultas Ekonomi Universitas Indonesia. 2006.

Nachrowi, Djalal Nachrowi dan Hardius Usman. Penggunaan Teknik Ekonometri. Jakarta: Raja Grafindo Persada. 2002.

Natsir, M. Ekonomi Moneter dan Kebanksentralan. Jakarta: Mitra Wacana Media. 2014.

Putong, Iskandar. Economics: Pengantar Mikro dan Makro. Jakarta: Mitra Wacana Media. 2013.

Rahardja, Prathama dan Mandala Manurung. Pengantar Ekonomi (Mikroekonomi dan Makroekonomi). Jakarta: Lembaga Penerbit Fakultas Ekonomi Universitas Indonesia. 2008.

Rahardja, Prathama dan Mandala Manurung. Teori Ekonomi Makro: Suatu Pengantar. Jakarta: Lembaga Penerbit Fakultas Ekonomi Universitas Indonesia. 2008.

Rozalinda. Ekonomi Islam: Teori dan Aplikasinya pada Aktivitas Ekonomi. Jakarta: Rajawali Pers. 2014.

Santoso, Singgih. Statistik Parametrik: Konsep dan Aplikasi dengan SPSS. Jakarta: PT Elex Media Komputindo. 2014.

Siamat, Dahlan. Manajemen Lembaga Keuangan. Jakarta: Lembaga Penerbit Fakultas Ekonomi Universitas Indonesia. 2004.

Siregar, Syofian. Metode Penelitian Kuantitatif: Dilengkapi Perbandingan Perhitungan Manual dan SPSS. Jakarta: Kencana. 2013.

Soemitra, Andri. Bank dan Lembaga Keuangan Syariah Edisi Pertama. Jakarta: Kencana . 2015.

Sudarsono, Heri. Bank dan Lembaga Keuangan Syariah: Deskripsi dan Ilustrasi Edisi 4. Yogyakarta: Ekonisia. 2013.

Sugiyono. Metode Penelitian Kuantitatif, Kualitatif, dan $R \& D$. Bandung: Alfabeta, 2016.

Sugiyono. Statistik untuk Penelitian . Bandung : Alfabeta . 2009. 
Islamiconomic: Jurnal Ekonomi Islam

Vol.8 No.2 Juli - Desember 2017

Sujarweni, V. Wiratna. Metodologi Penelitian Bisnis dan Ekonomi. Yogyakarta: Pustaka Baru Press. 2015.

Sukirno, Sadono. Makroekonomi Teori Pengantar. Jakarta: Raja Grafindo Persada. 2006.

Susilo, Y. Sri. Bank dan Lembaga Keuangan Lain. Jakarta: Salemba Empat. 2000.

Yuliadi, Imamudin. Ekonomi Moneter. Jakarta: PT Indeks. 2008.

Yuniarti, Vinna Sri. Ekonomi Makro Syariah. Jakarta: Pustaka Setia. 2016.

Yuwono, Prapto. Pengantar Ekonometri . Yogyakarta: Andi. 2005.

\section{Jurnal dan Skripsi:}

Anggara, Roma. Pengaruh Harga Emas Dunia dan Tingkat Suku Bunga The Fed terhadap Indeks Saham Syariah Indonesia (ISSI). Skripsi pada Fakultas Bisnis dan Manajemen Universitas Widyatama Bandung. 2014.

Dewanto, Agung. Pengaruh Inflasi, Harga Minyak Dunia, dan Dow Jones Industrial Average terhadap Indeks Harga Saham Sektor Manufaktur pada Perusahaan yang Terdaftar di Bursa Efek Indonesia Periode 2007-2010. Skripsi pada Fakultas Ekonomi Universitas Negeri Yogyakarta. 2014.

Istiqomah, Rahmatika. Analisis Pengaruh Inflasi, Jumlah Uang Beredar, Sertifikat Bank Indonesia Syariah, dan Harga Minyak Dunia terhadap Indeks Saham Syariah Indonesia (ISSI). Skripsi pada Fakultas Ekonomi dan Bisnis UIN Syarif Hidayatullah Jakarta. 2016.

Prabowo, Dimas. Analisis Pengaruh Inflasi, Sertifikat Bank Indonesia Syariah, dan Jumlah Uang Beredar terhadap Indeks Syariah yang Terdaftar di Indeks Saham Syariah Indonesia (ISSI). Skripsi pada Fakultas Ekonomi dan Bisnis UIN Syarif Hidayatullah Jakarta. 2013.

Rusbariandi, Septian. P. Analisis Pengaruh Tingkat Inflasi, Harga Minyak Dunia, Harga Emas Dunia, dan Kurs Rupiah terhadap Jakarta Islamic Index di Bursa Efek Indonesia. Skripsi pada Fakultas Ekonomi Universitas Gunadarma Jakarta . 2012.

Suciningtias, Siti. A. Analisis Dampak Variabel Makro Ekonomi terhadap Indeks Saham Syariah Indonesia (ISSI). Jurnal 2nd CBAM (Conference in Bussiness, Accounting, and Management Vol. 2 No. 1. 2015.

Syarofi, Faris Hamam. Analisis Pengaruh Suku Bunga SBI, Kurs Rupiah/ US\$, Harga Minyak Dunia, Harga Emas Dunia, DJIA, Nikkei 225, dan Hang Seng Index terhadap IHSG dengan Metode GARCH-M. Skripsi pada Fakultas Ekonomi Universitas Diponegoro Semarang. 2014.

Witjaksono, Ardian Agung. Analisis Pengaruh Tingkat Suku Bunga SBI, Harga Minyak Dunia, Harga Emas Dunia, Kurs Rupiah, Indeks Nikkei 225, dan Indeks Dow Jones terhadap IHSG. Skripsi pada Program Studi Magister Manajemen Universitas Diponegoro Semarang. 2010.

\section{Website:}

www.bi.go.id

www.ojk.go.id 
Octavia Setyani: Pengaruh Inflasi dan...

www.bps.go.id

\section{Catatan Akhir:}

${ }^{1}$ Abdul Manan, Aspek Hukum dalam Penyelenggaraan Investasi di Pasar Modal Syariah Indonesia (Jakarta: Kencana, 2009), 186.

${ }^{2}$ Kamaruddin Ahmad, Dasar-Dasar Manajemen Investasi (Jakarta: Rineka Cipta, 1996), 3-4.

${ }^{3}$ Abdul Manan, Aspek Hukum dalam Penyelenggaraan Investasi....., 189

${ }^{4}$ Nurul Huda dan Mustafa Edwin Nasution, Investasi pada Pasar Modal Syariah (Jakarta: Kencana, 2008), 8 .

${ }^{5}$ Siti Aisiyah Suciningtias dan Rizki Khoiroh, “Analisis Dampak Variabel Makro Ekonomi terhadap Indeks Saham Syariah Indonesia (ISSI)," dalam $2^{\text {nd }} C B A M$ (Conference in Bussiness, Accounting, and Management), Vol. 2 No. 1, (Mei 2015), 400.

6 Agung Dewanto, "Pengaruh Inflasi, Harga Minyak Dunia, dan Dow Jones Industrial Average terhadap Indeks Harga Saham Sektor Manufaktur pada Perusahaan yang Terdaftar di Bursa Efek Indonesia Periode 2007-2010", (Skripsi pada Fakultas Ekonomi Universitas Negeri Yogyakarta, 2014), 54.

${ }^{7}$ Septian Prima Rusbariandi, “Analisis Pengaruh Tingkat Inflasi, Harga Minyak Dunia, Harga Emas Dunia, dan Kurs Rupiah terhadap Jakarta Islamic Index di Bursa Efek Indonesia,” (Skripsi pada Fakultas Ekonomi Universitas Gunadarma Jakarta, 2012), 4.

${ }^{8}$ Septian Prima Rusbariandi, “Analisis Pengaruh..., 5.

${ }^{9}$ Faris Hamam Syarofi, “Analisis Pengaruh Suku Bunga SBI, Kurs Rupiah/ US\$, Harga Minyak Dunia, Harga Emas Dunia, DJIA, Nikkei 225, dan Hang Seng Index terhadap IHSG dengan Metode GARCH-M," (Skripsi pada Fakultas Ekonomi Universitas Diponegoro Semarang, 2014), 73-74.

${ }^{10}$ Iskandar Putong, Economics: Pengantar Mikro dan Makro (Jakarta: Mitra Wacana Media, 2013), 417.

11 Pratama Rahardja dan Mandala Manurung, Teori Ekonomi Makro: Suatu Pengantar (Jakarta: Lembaga Penerbit Fakultas Ekonomi Universitas Indonesia, 2008), 165.

12 Zaini Ibrahim, Pengantar Ekonomi Makro Edisi Revisi (Banten: LP2M IAIN "SMH” Banten, 2013), 97-98.

${ }^{13}$ Vinna Sri Yuniarti, Ekonomi Makro Syariah (Jakarta: Pustaka Setia, 2016), 143.

${ }^{14}$ Mahyus Ekananda, Ekonomi Internasional (Jakarta: Erlangga, 2014), 168.

${ }^{15}$ M. Natsir, Ekonomi Moneter ..., 301.

${ }^{16}$ Sugiyono, Statistika untuk Penelitian (Bandung: Alfabeta, 2009), 89.

17 Nur Indrianto dan Bambang Supomo, Metodologi Penelitian Bisnis (Yogyakarta: BPFE Yogyakarta, 2002), 148.

${ }^{18}$ Sugiyono, Metode Penelitian Kuantitatif ..., 85.

${ }^{19}$ Imam Ghozali, Aplikasi Analisis Multivariate dengan Program IBM SPSS 23 (Semarang: Badan Penerbit Universitas Diponegoro, 2016), 154.

${ }^{20}$ Imam Ghozali, Aplikasi Analisis Multivariate ..., 134.

${ }^{21}$ Imam Ghozali, Aplikasi Analisis Multivariate ..., 107.

${ }^{22}$ Imam Ghozali, Aplikasi Analisis Multivariate ..., 103.

${ }^{23}$ Sugiyono, Statistika untuk Penelitian (Bandung: Alfabeta, 2012), 260.

${ }^{24}$ Imam Ghozali, Aplikasi Analisis Multivariate ..., 98.

${ }^{25}$ Singgih Santoso, Statistik Parametrik ..., 105.

${ }^{26}$ Imam Ghozali, Aplikasi Analisis Multivariate ..., 97. 
Islamiconomic: Jurnal Ekonomi Islam Vol.8 No.2 Juli - Desember 2017 